\title{
Socio-political and security perspectives of Illegal Bangladeshi migrants in West Bengal: the impact on Indo-Bangladesh relations
}

\begin{abstract}
Illegal migration issue has been very crucial in Indo-Bangladesh relations. West Bengal is one of the sufferer states of Indian Union, which for a long time has witnessed of illegal Bangladeshi migrants. After partition of India, a large number of Hindu people had migrated from East Pakistan to West Bengal. In 1971, another influx of Bangladeshi refugees had entered into West Bengal. The flow of migrants and infiltrators has not been stopped yet. The migrants of Bangladesh are concentrated in the bordering districts of West Bengal. This issue is very sensitive. There are so many inter-connected factors of illegal Bangladeshi migrants in society, politics and economy of West Bengal. The security aspect is very important in the context of present scenario of West Bengal. Bilateral diplomatic relations is often influenced by illegal migration issue. This paper intends to delineate the various perspectives of illegal Bangladeshi migrants in West Bengal and it will further focus on the impact of illegal migrants on Indo-Bangladesh relations.
\end{abstract}

Keywords: illegal, migrants, diplomatic, security, West Bengal
Volume 4 Issue 3 - 2019

\section{Debasish Nandy}

Associate Professor, Department of Political Science, Kazi Nazrul University, West Bengal, India

\begin{abstract}
Correspondence: Debasish Nandy, Associate Professor, Department of Political Science, Kazi Nazrul University, West Bengal, India, Tel +9|-98303 |8683,
\end{abstract}

Email debasishnandy.kc@gmail.com

Received: May 27, 2019 | Published: June 28, 2019

\section{Introduction}

Migration is a globally debatable issue today. It has so many dimensions. The migration issue can become more complicated when the flow of infiltration continuously goes on from one country to another country. Illegal migration can be discussed through the lens of Linkage Theory. The impact of illegal migration has vehemently affected Indo- Bangladesh relations. Illegal immigration is the illegal entry of a person or a group of persons across a country's border, in a way that violates the immigration laws of the destination country, with the intention to remain in the country, as well as people who remain living in another country when they do not have the legal right to do so. Illegal immigration, as well as immigration in general, is overwhelmingly upward, from a poorer to a richer country. Today one of the major issues in Indian politics is illegal Bangladeshi migration. The controversy between the legal and illegal migrants and controversy between Hindu and Muslim Bangladeshi migrants have been a new issue of debate in India. This issue has not been confined within India only; it has been an international issue. The governmental policy of "push-back" has created a new problem on Indo-Bangladesh relations. After the declaration of NRC (2019) in Assam the Bengali community of Assam is puzzled about their citizenship. A large number of Bengali speaking Hindu and Muslim people had entered Assam before and after 1971 war. That is why the "son of soil" slogan has been raised by the Assamese leaders to push-back the Bangladeshi people to Bangladesh. The policy of deportation has not been finalized yet. In case of West Bengal situation is different. Here the state leaders of TMC, Congress and CPI (M) are very generous towards the Bangladeshi migrants. There are so many inter-related reasons behind the soft corner of leaders towards the migrants. However, the policy of state BJP leaders towards the migrants is quite similar with the present government. There are so many dimensions of this research. I have observed the entire bordering districts of West Bengal, on the basis of which I have drawn a canvas of illegal migrants in West Bengal.

\section{Reasons behind the migration}

The reasons for a person to either migrate voluntarily or being forced to leave his home are complex are intertwined. Social, political, economic and environmental compulsions back home, or even personal whims, could affect a person to cross the borders and settle in a new country. In the case of Bangladesh, a host of political and economic factors, such as political upheaval, religious persecution, social insecurity, economic stagnation and absence of job opportunities, demographic pressures and environmental crises, have pushed its nationals to leave their homes and migrate to India. At the same time, availability of land, better economic opportunities, education and health facilities and a similar cultural landscape have attracted these migrants to settle in India.

\section{Understanding migration and refugee problem}

Migrants are those people who move away collectively from one geographical location to another in search of better livelihood. On the other hand, refugees are those people who leave their country due to civil wars, communal riots, wars, ethnic conflicts. When these cases of movement and dislocation occur in a collective manner involving groups like families, communities, or nations, it is called migration. It can be voluntarily as well as involuntarily. The basic difference between the two kinds is that in the case of voluntary migration, the migrants have the scope to make their own decisions whether or not to move, but in cases of involuntary ones, the migrants do not retain any scope of independent decisions. Involuntary migration can be called forced migration in political terms. Any kind of migration occurs because of certain reasons. Battered against the natural urge for survival, 'nation' and 'border' are easily marginalised in the minds of the people who have received continuous threats to their existence from persecution and discrimination in their country. In such circumstances they find 'illegal' ways to tackle this obstacle in the path of their well-being. When people cross the borders without 
any legal authorisation then it becomes illegal migration. Migration and Refugees become a problem in international terms when they affect the relations between countries badly. If people are forced by the circumstances to migrate to some other country, the other country should give them refuge on humane grounds.

\section{Bangladeshi migrants in some districts of West Bengal}

In West Bengal the concentration of Bangladeshi migrants are found in North 24 Parganas, Nadia and Murshidabad and Cooch Behar districts. However, the ratio of Bangladeshi migrants in all districts is not same.

\section{Migration in the district of 24 parganas (North)}

One of the major Bangladeshi migrant's concentrated districts is 24 Parganas (North). This district shares border with Bangladesh. Ichamati River has been flowing between the two countries. Bangon and Bashirhat these two sub divisions are very significant for entry of migrants. Since 1947 the migrants East Pakistani (now Bangladesh) citizens are entering in West Bengal after crossing the borders of 24 parganas (N). In 1971, the influx of refugees has taken entry into 24 Parganas $(\mathrm{N})$. The flow of migrants has not been stopped yet. Illegally they are taking entry through a number of illegal entry points. They are crossing Ichamati by boat. I have visited the entire bordering area of these districts. I have noticed that a large number of bordering areas people is directly involved in trafficking of illegal migrants. The local economy is basically based on agriculture. In order to eliminate financial crises, the people of bordering area in Indian side have been involved in illegal trafficking of Bangladeshi citizens. Local Mafias, leaders, polices and BSF are involved in this activities. In 1992, another influx of refugees' has shown in this district due to communal riot in Bangladesh.

This district is highly populated. The Hindu-Muslim ratio is very neck to neck. The migrants who came from Bangladesh after 1971, most of them are Hindu. The economically reach people have taken shelter in urban pockets like Barasat, Habra, Madhamgram, New Barrackpur, Sodepur, Belgharia and Dum Dum area. After settling here the Bangladeshi migrants have been involved in many different professions. In the beginning, the poor Hindu migrants had tried to take shelter in their relative's house or nearby. In an observation it has been noticed that primarily, the economically poor migrants had to struggle a lot for their livelihood, citizenship and permanent shelters. In Congress period, Bangladeshi migrants were given lands in various areas of this district. Per family was given certain area of lands to build their house totally free of cost or taking a minimum amount. In New Barrackpur Municipality area, more than $75 \%$ people are from East Bengal. They have been settled down after 1950. In 1960-70 this area was developed. The local leaders had helped them in getting citizenship.

\section{Political implications of bangladeshi migrants in the district of 24 parganas (North)}

In politics of West Bengal, Bangladeshi migrants have a great contribution. In many cases, they are determinants of elections. The proposed research project intends to investigate the socio-economic and legal aspects of Bangladeshi migrants in bordering districts of West Bengal. In many times, the clashes between the local people and the migrants occurred. In recent years, West Bengal has witnessed many such types of communal riots. The most of the cases were held in bordering districts. The emergence of JMB, the Bangladeshi
Islamic terrorist group in West Bengal has been a great security threat for west Bengal. The infiltrated young Muslim people of Bangladesh have settled in the rural Muslim concentrated areas. They are either the follower of Radical Islamic groups or the member of a particular group. After the Khagragar incident of Burdwan District in 2014, the illegal migration issue manifested to the government. In many areas, the price of lands has increased rapidly due to Bangladeshi migrants. Political patronage given to illegal migrant is yet another factor which has encouraged millions of undocumented Bangladeshis to settle in India illegally. Political parties have always exploited the vulnerability of the illegal migrants for their own vested interests and benefits. In the pre-independence era, the Muslim League government of Saadullah encouraged thousands of Muslims from East Bengal to settle in Assam with the objective of transforming the demography of Assam and making it a Muslim-majority province which could be claimed by Pakistan. ${ }^{1}$ Post-independence, the situation did not change much. Although there were periodic demands for the expulsion of illegal migrants, the process of detection and deportation itself was not robust enough and crumbled under political pressures. In fact, efforts to deport illegal migrants encountered protests from political parties, who blamed the executive for harassing Indian Muslims in the garb of expelling Bangladeshis staying illegally in the country. ${ }^{2}$

The keys reason that the political parties protect the illegal migrants is that they consider the illegal migrants as potential vote banks that need to be nurtured and sustained. For this purpose, they have facilitated the stay of the illegal migrants in India by providing them with fake Voter Identity Cards and Ration Cards, which establish that they are Indian citizens with voting rights. And whenever there has been a demand to deport the illegal migrants, politicians of almost all affiliations have protest against it. Leaders like Siddhartha Sankar Roy, Jyot Basu and Buddhadeb Bhattachariya are originally from East Bengal. So there is an ethnic sentiment which motivated the predecessor leaders of West Bengal to consider the factor carefully. In this connection I would like to mention the infiltration of Tamils in Sri Lanka from Tamil Nadu. During the British period a large number of Tamils had settled down in Sri Lanka, especially in Jaffna and Kandy areas. They were working force of British companies. They used to work in various rubber garden, coffee and tea plantation.

\section{The politicization of matua community}

Matua community is a unique sect of lower caste Hindu who are originally migrated from East Pakistan or Bangladesh. This community is marginalized and belonged to Namasudra. In different times, the matua people had entered in West Bengals. The religious master of this community was Harichand Thakur. Matua Thakur bari is located in Thakurnagar in the district of 24 Parganas $(\mathrm{N})$. After his death his wife became the mother and guardian of this community. Now, most of the family members of matua Thakur bari attached with politics. The followers of Thakur family are big in number. Matua family has been divided into two political parties---BJP and TMC. The matua people are a big vote bank for all political parties. The politicization of matua community has been an issue of political equation in West Bengal. In the 1960s, the Communists were able to champion the cause of these refugees and attack the ruling Congress for ignoring them. Significant refugee support made the Communist Party of India (Marxist) into a major player in the state. Later in 2009, the TMC reached out to the Matua Mahasangha - a socio-religious organisation consisting almost entirely of Bangladeshi immigrants - and used their votes to dethrone the Left Front. Now the BJP is 
pushing the Hindu immigrant cause in the hope that it can replicate the Communist Party of India (Marxist) and TMC's success in netting the bloc. The party even has a refugee cell, set up in 2014, before the Lok Sabha elections. Local Hindu residents blamed the Trinamool Congress administration for appeasing the rioters. However, many Muslim residents, like Islam, also traced back the communal sentiment in the area to the existence of large numbers of Hindu immigrants from Bangladesh. In the Lok Sabha Election of 2014 and 2019 the entire community has been polarized. Due to the political power equations Matua family has been politically divided. The religious based community for the lower caste Hindu now has become a 'politicized community'. Previously the vote bank of Matua community was dividends between TMC and CPI (M). Now it has been divided between TMC and BJP. Before the commencement of 2019 Lok Sabha election, Naraendra Modi also visited and delivered a speech in Matua area.

\section{Nadia}

Nadia district is another Bangladeshi migrant's concentrated district. Most of the Bangladeshi migrants had taken entry through Gede border. The people of Bangladesh from the district of Rajsahi, Kustia, Pabna had entered through this border in 1947 and second time influx of Bangladeshi migrants have entered in 1971 during the liberation movement of Bangladesh. The agro-based economy of this district is not impressive. The marginalized lower caste Hindu people are leaving in rural area. They are attached with farming. The Cooper's Camp is the biggest refugee camp in the district of Nadia. For the last 72 years the inhabitant of cooper's camp are living with so many challenges. The number of population is 7000 . The migrants had left East Pakistan during and after partition. Most of them were forced to handover their property to Muslims in their native place. Cooper's camp is the oldest and least-known refugee camp in the South Asian region. Cooper's camp is a notified area. The people of this area is a small vote bank for political parties and also important for law and order. I have taken the interview of Sri Pankaj Dutta, former I.G of West Bengal Police. He was also at the top position of State Intelligence. He had served as the S.P of Nadia district from 2001-2006. He had successfully handled the law and order of the Nadia district. During 2001 and 2006 state assembly elections political violence took place in different parts of this border district. The Bangladeshi migrants have-always played a key role in the elections in Nadia.

\section{Murshidabad}

Murshidabad is another poorest and corrupted district in West Bengal. There are no legal entry point of Bangladeshi people in this district. This district has been defamed for illegal cattle trade and smuggling. It is true that there are some points through which illegally Bangladeshi people take entry. This district is highly Muslim concentrated. The Lalgola area is of this district is famous for illegal Bangladeshi entry. But the flow of Bangladeshi people is very less in comparison with other districts. People are coming in India for business and work. The illegal migrants are from illiterate and marginalized Muslim community of Bangladesh. They used to go Gujarat, Mumbai, Delhi, Kerala and other places for work. They are manual workers. Without having any valid documents they are taking entry through porous border by paying a certain amount to the local leaders and touts. This money is distributed among BSF and BDR. The local police is also receive certain amount of money. There is a big racked of illegal activities in this districts. Some Young guys are often crossing the border with the local people, especially the villagers of the border areas. They got married with bordering areas Muslim girls and they return back to Bangladesh. I have visited the Lalgola area to investigate the facts. This area is strategically important due to Padma River. Lalgola is situatesd on the curve of Padma River from where Padma has taken entry into Bangladesh. There is a historic legacy of this district. Nawab Shiraj-ud-daula was the Nawab of this district. The culture and demographic structure is very different and complex than other districts. In Murshidabad district the number of Hindu migrants is very few. I have talked to Md. Akbar Ali. His residence is in a bordering village of Lalgola block. He is an M.Phil. Students of Jadavpur University, Kolkata. He has described elaborately about the actual scenario of illegal migrants. I took interview of Md. Hafiz Sekh.

Murshidabad is a Muslim majority district. During Nawab Murshid Quli Khan, the conversion of Hindu to Muslim process was started. The lower caste Hindu people at a large scale were converted into Islam. Before independence this community was backward, after independence the situation is almost same. Most of the rural families are attached with agriculture, silk handloom and biri binding work. The illiterate guardians are still ignoring to send their child to school. Government has taken plenty of initiatives towards policy of 'education for all'. Through Sarbo Siksha Avijan and establishing of new schools in remote villages government is trying to spark the education to first generation learners. I have taken an interview of Nazrul Islam (IPS). He was an IPS, belonged to a marginalized illiterate Muslim family. He told me, he was the first secondary passed person in his village. He was also the first graduate of his village. There was no primary School in till 1995 . He initiated to establish a primary school in his village. He graduated from KN College of Bharampur, the district town. He had to travel $70 \mathrm{KM}$ every day. He was the first IPS in his district during that time. To him, now time has been changed, but situation is also little bit changed. A number of polytechnic colleges have been established in Domkol Sub-division, where he belongs to. Actually, he categorically, mentions that in spite of governmental initiatives, the quality of education has not been ensured. He told me, socioeconomic constraints are remaining the major factor. Traditional rural mind-set has not been changed yet. Social mobility is not enough. There is a common trend among the teen-agers to work in outside of Bengal. Due to poverty and expectation of earning thousands of students ageing 12-16 are going to Gujrat, Maharastra, Kerala and Delhi. There is a common feature both of Malda and Murshidabad that is illegal cattle trade and smuggling in border area. A large number of people of these two districts, especially in border areas are attached with illegal cross-border trade. So, there is a common trend among the High School going students to attach with this illegal business. The illiterate family members are reluctant about the future of their child.

\section{Cooch Bihar}

Cooch Bihar is one of the backward districts in West Bengal. Due to this reason, a number of first generation learners are stopping their education before the completion of their school education. Cooch Behar district has its own distinct feature. It has a common border with Bangladesh and Bhutan. Ethnically, most of the Cooch Behar's people are different from main stream Bengali people. Cooch Behar had a rich tradition of culture during the Kingship. The Rajbanshi community of this district was no ready to accept post-independent educational system of West Bengal. Most of the population belong to SC and ST category. Demographical picture of Cooch Behar shows 
that there are thousands of migrants, who infiltrated from Bangladesh, Bhutan and Assam.

The Cooch Behar case is quite different from others. In this district there are numbers of disputed or controversial lands which are known as enclaves or chitmahals. Even, after 72 years of independence the enclave dwellers are facing tremendous problems. Most of the people are marginalized and attached with agriculture and illegal cattle trade. Availability of primary schools is microscopic in terms of number. There is no high school and college in enclaves'.Enclave (Chitmahal in Bengali) means a portion of territory of one state surrounded by territory of another or others, as viewed by the surrounded territory. ${ }^{3}$ There are a good number of enclaves all around the world, which were created for a variety of historical, political or geographical reasons. An enclave can be defined as a portion of one state completely surrounded by the territory of another state. From the point of view of the state in which it is located it is termed as an enclave and the state to which it belongs is an exclave. ${ }^{4}$ But both enclave and exclave would be termed as enclave in this paper as this is the most commonly used term. Bangladesh and India share 162 enclaves between them among which 111 belong to India, and 51 belong to Bangladesh. During the study, the respondents of the enclaves expressed their satisfaction regarding the social security in recent times. Situation of enclaves' people was so bad. However, the situation has changed since. In July 2011, India and Bangladesh started conducting a joint census of the enclaves. In the process, the Joint Boundary Working Group counted 51.590 people in enclaves on both sides of the border and claimed to have given house numbers to all residents. This figure completely belies what would now seem to be the over exaggerated academic estimates. However, the census figures have not been universally accepted, least of all by the Bharat-Bangladesh Enclave Exchange Coordination Committee (BBEECC), an organization fighting for the rights of enclave-dwellers. Though very few $(2.6 \%)$ of them reported some incidents of physical tortures done by BSF people. A member of 'Citizen Rights Forum', Mr. Diptiman Sengupta, has expressed his tension about enclave dweller's education system. He told due to governmental negligence towards this controversial area, school education is terminally ill and college education a utopia.

However, agro-based economy and absence of heavy industry caused high rate of illiteracy. Numbers of high schools are not sufficient. In interview, few students told, they have no books, school dress. They have to suffer starvation in many times. So, they have to help to their parents in their family business. On, the other hand, parents have expressed their disappointments about the future of their children. They told, as they are financially challenged, that is why, they are doubtful about the further education of their children. There was no university in this district. In 2009, district got its first university. But, still now it is not well-equipped. Previously, students had to go more than $100 \mathrm{~km}$ for their higher education. Before, 2009 the nearest university was North Bengal University. I have talked with Professor, Anil Kumar Biswas, a Faculty member of Burdwan University, West Bengal about the current status of first generation learners of Cooch Behar District. He told me, 'he himself is a first generation learner. He had to walk 10 K.M to reach his high school and for college he had to journey $80 \mathrm{~km}$ every day. He told it is a common scenario of Cooch Behar district. He also belonged to a valid migrated family. His forefather had come to India in 1950s. They had to struggle a lot. From the very beginning his family members were involve in agriculture. Most of the Bangladeshi migrants in Cooch Behar are by profession farmers. This district is industrially backward.
The demographic picture of this district is very significant due to the huge presence and strong foothold of Rajbanshi community. They are the indigenous people of this district and they are the Bhumiputra (the son of the soil). There is an undercurrent in society and politics of this district regarding the identity of Kamtapuri people. The Rajbanshis are also known as Kamtapuri. For a long time they are demanding a separate state. They formed the KLM. This is a party as well as organization which is demanding and struggling a separate state with violent means. Toto is primitive tribal group. This group is scattered. It is concentrated in several parts of North Bengal, especially in Cooch Behar. The first generation literacy rate of Toto is 20 per cent. Two Toto girls completed graduation for the first time in 2014. Both of them studied in Kolkata and presently preparing for competitive examinations. There is a primary school but no high school so far. In this case, Government of West Bengal has taken special care for restoration of Toto culture and sparks the light of education.

West Bengal having an agricultural-based rural economy face myriad of livelihood issues and infrastructural deficiencies. A welldesigned educational infrastructure can assure greater access to knowledge, which in turn will make people capable and help in holistic development. But West Bengal's progress in achieving priority educational objectives has not been encouraging, particularly in the rural sector.

\section{Bangladeshi migrants in West Bengal: the legal and security aspects}

The illegal migrants have managed their Ration Cards and Voter Cards by paying and managing touts and local politicians. It is true that, the Hindu people are coming from Bangladesh continuously. A handful number of Muslims are crossing the borders and settling in minority areas. Some of them have changed their name and arranged their Indian document and they got married with Indian Muslim girl. They are also purchasing lands. They are availing loans and other facilities from the state governments. It has been observed that a few number of minority migrants have been attached with terrorism and illegal trafficking. They are working as the agent of JMB. They have a close link with worldwide terrorist links. Some young people are coming to West Bengal illegally. They are accused with non-billable crimes. This is very much a security threat to India.

For the last few years, a large number of Bangladeshi migrants have entered Kolkata through various borders. Few of them have been arrested for not having valid documents in taking entry into India. Some political leaders are taking shelters in West Bengal. There are many cases in their names in Bangladesh for involving criminal activities. To escape from police and judicial charges they are leaving their country and taking shelters in Kolkata surrounding areas. Recently, a number of criminals and terrorists have been arrested by Kolkata police and West Bengal police. There is a strong network of Bangladeshi terrorists in West Bengal. They are very active in managing relevant documents of Indian citizenship. Despite taking so many safety measures Indian intelligence often fail to identify the Bangladeshi criminals. The illegal Bangladeshi criminals are managing the Indian documents by giving huge amount of bribes.

One of the major problems in bilateral relations between India and Bangladesh is illegal migration. Over the decades after partition, millions of East Pakistani peoples had taken shelter in the bordering districts of West Bengal. Till the end of Bangladesh Freedom struggle of 1971 the East Pakistani migrants were considered as legal. The 
government of India arranged foods and shelters, even in several cases lands also. In humanitarian ground, government of India also give them citizenship. After 1971, when Bangladesh became a sovereign state led by Sk. Mujibur Rahman, then primarily the trend of Hindu migration towards India specially, in West Bengal was stopped. After his assassination, the subsequent pro-Pakistani rulers were not generous towards religious minorities. Due to the policy of persecution towards the Hindu, thousands of Bangladeshi people took shelter in different parts of West Bengal.

There are many Bangladeshi migrants in West Bengal who are staying in different prisons. The question of security, legality and humanism are very crucial in this regard. The migrants who are 18 years of age are in various homes under the custody of Ministry of Child and Social Welfare. The juvenile courts are very active for their judgements. Sri Subham Das was a supervisor of a home of Baharampur town in Murshidabad district. I took his interview. He told me that every year a number of marginalized Bangladeshi people enter Murshidabad through the unrecognized entry point. Women and men are sent to the prisons and below 18 years Bangladeshi migrants are sent to different homes.

In recent times, there is also an ethno-communal dimension to the security question in respect of illegal Bangladeshi settlers in India. Partha S. Ghosh has rightly observed that "most of the villages on the India-Bangladesh border are Muslim-majority villages; there has been the danger of Inter-Services Intelligence (ISI) operations in these areas. The Islamic connections of these migrations are evident from the growth of Madrasas." "Through audio cassettes and videos the ISI is trying to propagate the radical Islamic ideology. A number of illegal madrasas have been built-up my radical Islamic leaders and they are trying to inject the poison of fundamentalism among the youngsters of Muslim community. Through different land borders and water-ways Bangladeshi terrorists are taking entry in bordering areas and later on they are going in different places of West Bengal. The Khagragarh incident of Burdwan town (2014) was the manifestation of Bangladeshi illegal infiltrators. The provocative speeches of Azar Masood and Zakir Nayek were very popular among the uneducated Muslim youths in bordering areas. After coming into power the Taliban government of Afghanistan wanted to make the entire South Asia as Talibanistan. In order to enhance the process of Talibanization in Bangladesh, a number of plans were taken by Taliban in association with JMB and other radical Islamic organizations. In many cases, Bangladesh based terrorists have entered in bordering areas and they supplied the booklets of jihad in order to act against the Indian national security. ISI of Pakistan is very active in border areas. ISI had tried to install indigenous satellite telecommunications near Dum Dum airport. As per the data of Indian intelligence, two-ISI operated international telecommunication centres or secret spy exchanges were seized by the Indian authority. Rajarhat and New Town areas are newly developed townships. This area is less populated. There are some guest houses, hotels and apartments from where suspected Bangladeshi peoples are being arrested. Partha S. Ghosh has mentioned four interrelated factors are responsible for internal security threats in West Bengal, which are as follows:

(1) The overall Hindu-Muslim politics of India;

(2) The growth of international Islamist terrorism and the jihadist threat posed to India by elements in Pakistan and Bangladesh with the help of their conduits on Indian soil;
(3) The nexus between politicians, illegal migrants drug traffickers, smugglers and other black money racketeers and

(4) The federal structure of security architecture.

Presently, there are no noticeable hazards of Pakistani migrants in India. Due to tight border in western part of India the Pakistani infiltrators are being restricted to enter in India. India shares long border with Bangladesh. The entire border line is not covered by fencing. I have noticed in 24 Parganas $(\mathrm{N})$ districts that in many places there is no fencing. In some places fencing is cutup by the criminals. The deployment of BSF is not satisfactory. A BSF camp is situated long distance from another. For per kilometre there is only one BSF is assigned. I talked to the local people and BSF about the security. They told more Border Security Forces are required for securing the boundary. Rajindar Singh, a BSF Jawan has told that they are helpless to ensure tight security in bordering area due to shortage of Jawans. They are not permitted to shootout the illegal infiltrators. The Ichamati River is flowing between the two countries. I found a speed boat for patrolling on the river. Due to unsecured and porous border, illegal migration and infiltration are going on. The ISI people and other terrorist groups are taking this opportunity.

I have taken few snaps in Indo-Bangladesh border in Bangon subdivision where Ichamati River is flowing. The Bangladeshi people regularly have their birth on the other bank of the river. I have seen that many Bangladeshi people were swimming. They can easily cross the river any time. The surveillance of BSF was not noticed by me. To be confirming, I talked to the local people regarding the security and surveillance. I did not get any positive response. The opposite bank of the river is situated in Jessore district of Bangladesh. Most of the trafficking cases occur at night time. Previously, there was no searchlight in border areas. Now in some areas few light stands have been installed.

Khagragarh incident is well known terrorist activities in contemporary India. Khagragarh is a Muslim concentrated area of Burdwan town where in a rented house some Bangladeshi JamaatulMujahidin Bangladesh (JMB) members were leaving with an aim of spreading terrorist activities in different parts of West Bengal. After this incident the central government wanted to probe the actual facts behind this incident. Central government has sent (National Investigation Agency (NIA). The government of West Bengal was not happy for sending the NIA team in Burdwan town. The entire situation turned into a political game. However, some information was received from the lady who was the wife of the main criminal.

\section{Migration problem: the impact on Indo-Bangladesh relations}

One of the major problems in bilateral relations between India and Bangladesh is illegal migration. Over the decades after partition, millions of East Pakistani peoples had taken in bordering districts of West Bengal. Till the end of Bangladesh Freedom struggle of 1971 the East Pakistani migrants were considered as legal. The government of India arranged foods and shelters, even in several cases lands also. In humanitarian ground, government of India also give them citizenship. After 1971, when Bangladesh became a sovereign state led by Sk. Mujibur Rahman, then primarily the trend of Hindu migration towards India specially, in West Bengal was stopped. After his assassination, the subsequent pro-Pakistani rulers were not generous towards religious minorities. Due to the policy of persecution towards 
the Hindus, thousands of Bangladeshi people took shelter in different parts of West Bengal.

The history of the world is the history of migration. Migration has taken place since time immemorial and will continue in future. People have migrated to distant lands in search of food, shelter, freedom, security and better lifestyle, and in the process have made an impact on the socio-economic, cultural as well as the political fabric of their destinations. Consequently, migration has come to be increasingly regarded by the elites of the receiving country as a threat to the greater political and societal integration, and therefore a security risk. As countries try to restrict the influx of people into their territory, migration gets closely linked with border control, terrorism and criminality, resulting in its securitisation. ${ }^{6}$ Out-migration from the plains of East Bengal into India did take place during the colonial times too, but the partitioning of the Indian subcontinent and the subsequent cycle of violence and counter-violence in 1950 triggered a massive movement of people across the borders of the newly created India and Pakistan.

India is often described as a land of migrants, which over centuries has attracted streams of immigrants from different races and cultures and assimilated them to build a composite civilisation. The atrocities against the Hindus in East Bengal resulted in widespread communal riots in West Bengal thereby disturbing societal harmony. ${ }^{7}$ The liberation of Bangladesh in 1971, and India's acceptance to absorb all illegal migrants from East Pakistan who had migrated before March 24,1971 , introduced a period of lull in the charged up atmosphere. The calm was however short-lived as Bangladeshis (both Hindus and Muslims) continued to enter India illegally till mid-1970s. Since that time People have been moving from one part of the country to the other for social, economic (trade), cultural and ethnic reasons. But this movement became a problem only after India was divided in 1947 and this part became province of Pakistan and was known as East Bengal till 1956 and as East Pakistan from 1956 to 1971.

Smriti S. Pattanaik has shown in her research paper that in case of forced migration, where the country of origin or its fundamentalist forces have intentionally driven the migrants out of the country, the refugees find themselves in such a situation where they never get favourable conditions of a safe return. The provisions of international law do not permit the host country to exile the refugees from its territory and any agreement with the country of origin is generally not possible easily, as most of the refugees are illegal migrants and they do not carry any valid documents. This makes the matter of Migration and Refugee issue between India and Bangladesh more complicated. ${ }^{8}$

For domestic political reasons while Bangladesh remains silent on the issue, India highlights the issue for the same reasons. The issue of illegal movement is now addressed within the larger framework of human trafficking. The Ministry of Home Affairs of Bangladesh in the 2012 Annual report defines trafficking as, "the end-object of this crime is commercial sexual work, forced labour, prostitution, or other forms of exploitation. As such, unsafe/irregular migration always runs the risk of human trafficking." Bangladesh is not ready to accept that Bangladeshis are illegally migrating into India. Nevertheless, the bilateral Task Force of Bangladesh and India has been established in order to minimize the crisis. Both countries have put in place joint Coordinated Border Management Plan (CBMP) signed in July 2011, the problem however continues. The reason is while there is night curfew on the Indian side of the border there is no such restriction on the other side. The BSF points out that the compulsion for border patrol for the Bangladesh Border Guard is less apart from the problem that their Border outposts are situated far apart from each other. It is also Delhi-Dhaka relations that influence the border cooperation dynamics. Ranabir Samaddar seems it is a fact that South Asia contributes to the foreign working forces in the Middle East, Europe, East Asia and other part of the world. Therefore, how long Bangladesh can "officially deny that 'unofficially' any coming over is taking place". ${ }^{10}$ The need is how to go beyond the zero sum game and address the issue. Sanjay Hazarika has pointed out, "the social, demographic and political tensions spawned by this problem are too deep to gloss over or to seek quick-fix solution like 'throwing' foreigners out." 11

\section{Conclusion}

After the partition, millions of East Pakistani people had taken entry into India through different entry points. Due to infiltration and influx of migrants lots of controversy, debates and politics have been generated. The additional hazard of illegal migration is security. It is very difficult to identify the refugees from the migrants. Today migration politics has been a major element of West Bengal politics. Illegal migrants often create negative socio-economic impact. Hiranya Kumar Bhattacharyya has suggested that Indo-Bangla border must be completely sealed in all the states bordering Bangladesh. The quality of the border fencing must be the same as on the Punjab border, an area of about hundred meter width, must be cleared of all human habitation and vegetation all among the Indo-Bangla border. He also suggested that the entire bordering areas must be put under dusk to dawn curfew with flood-lighting arrangements. ${ }^{12}$ It is needed to install the CCTV cameras for continuous surveillance. The government of India should continue its dialogues and talks regarding this issue with Bangladesh tactfully. The enemy states can take the opportunity of porous border between India-and Bangladesh. The numerous IndoBangladeshi enclaves, which are sprinkled along the international border of Bangladesh and India, are collectively known as chhitmahal and constitute a bizarre political geography. Atig Ghosh in his research has shown that most of these enclaves are in the Cooch Behar and Jalpaiguri districts of West Bengal, India, and in the Kurigram, Nilphamari, Lalmonirhaat and Pachagarh districts of Bangladesh. In his magisterial study of the enclaves of India and Bangladesh, Brendan R. Whyte tells us there are exactly 198 enclaves in total-106 Indian enclaves in Bangladesh and 92 Bangladeshi enclaves in India. ${ }^{13}$ Many Bangladeshi women who are illegally entering India are also being arrested as illegal migrants. ${ }^{14}$ The women and child trafficking are two alarming issues for Bangladesh. Through the different borders the touts and criminals are trafficking the women's and Childs'. The issue of illegal immigration would be addressed within the larger issue of human trafficking as it remains a politically difficult subject.

Regarding the NRC issue Indian politics has been very hot today. It is very difficult to identify the legal migrants from the illegal migrants. This issue is very sensitive and complex. The view of Congress is different from BJP. Congress party has a soft corner about the Bangladeshi migrants. Socio-economic aspects of illegal Bangladeshi migrants are subject to politics and security. The politicization of Bangladeshi migrants in West Bengal has created a negative impact. The government of West Bengal, Central government, intelligence and BSF should be aware about illegal immigrants. The politics of illegal migration is not expected.

\section{Acknowledgments}

None. 


\section{Conflicts of interest}

Author declares that there is no conflict of interest.

\section{References}

1. Rizwana Shamshad. Bangladeshi Migrants in India: Foreigners, Refugees or Infiltrators? New Delhi: Oxford University Press; 2017. p. 143.

2. Praskanya Sinharay. To Be a Hindu Citizen: Politics of Dalit Migrants in Contemporary West Bengal. South Asia Journal of South Asian Studies. 2019.

3. Metcalf, Jonathan, Thompson. DK Illustrated Oxford Dictionary. UK: Della Dorling Kindersley Ltd and Oxford University Press; 2003.

4. Van Schendel W. Stateless in South Asia: The Making of the IndiaBangladesh Enclaves. The Journal of Asian Studies. 2002;61(1):115-147.

5. Partha S Ghosh. Migrants Refugees and the Stateless in South Asia. Sage. 2016. p. 151.

6. Jef Huysmans. The European Union and the Securitization of Migration. Journal of Common Market Studies. 2000;38(5):762.

7. Pushpita Das. Illegal Migration from Bangladesh: Deportation, Border Fences and Work Permits. IDSA Monograph Series, No. 56, 2016.

8. Smruti S Pattanaik. Politics of Illegal Immigration and India Bangladesh Relations. 2019.
9. Ministry of Home Affairs. Combating Human Trafficking: Bangladesh Country Report. 2012.

10. Ranabir Samaddar. The Marginal Nation: Trans border Migration from Bangladesh to West Bengal. Delhi: Sage; 1999. p. 58.

11. Sanjoy Hazarika. Rites of Passage: Border Crossing, Imagined homelands, India's East and Bangladesh. Delhi: Penguin; 2000. p.7.

12. Hiranya Kumar Bhattacharyya. Operation Lebensraum: Illegal Migration from Bangladesh. New Delhi: Bloomsbury; 2018. p. 188.

13. Atig Ghosh. Chhitmahal: The Defacto Stateless of the Indo-Bangla Border in his and Sucharita Sengupta Paula Banerjee written. West Bengal Bangladesh Borders: The Humanitarian Issues. Calcutta Research GroupL Working Paper no.68, 2015.

14. For betterment of life a number of girls are taking entry into India illegally. There are so many cases where women's are brought from Bangladesh to the metropolitan towns in India face tremendous brutality. One such case is that of Abeda Khatun a young Bangladeshi girl school going girl was, who was brought to India at the tender age of ten. She "suffered a series of brutal rapes at the hands of the man who brought her to New Delhi, along with some of his friends who were Delhi policemen. Many girls and women's are taking entry illegally in India and sending by touts to different big cities India. 